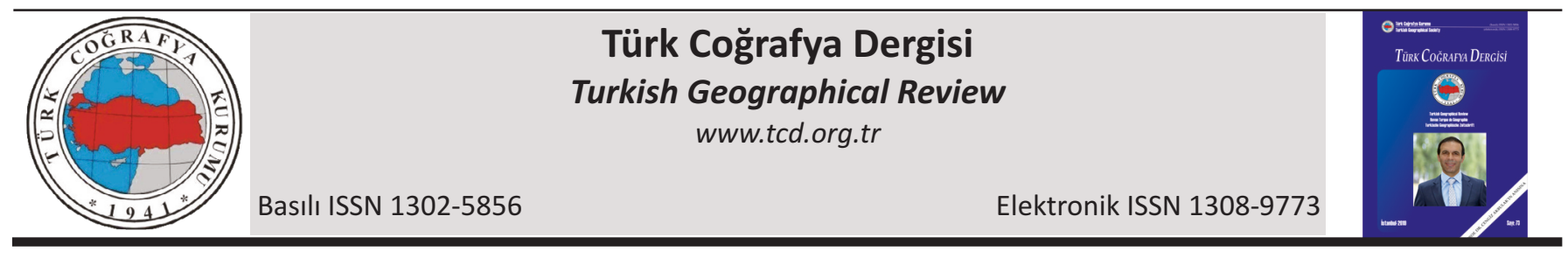

\title{
Salda Gölü özel çevre koruma bölgesinde turizm baskısı, koruma ve sürdürülebilirlik
}

\section{Tourism pressure, protection and sustainability at Salda Lake which is special environmental protection area}

\author{
Serdar Ceylan ${ }^{\mathrm{a}}$ (i) Ihsan Bulut ${ }^{\mathrm{b}}$
}

${ }^{a}$ Mehmet Akif Ersoy Üniversitesi, Fen Edebiyat Fakültesi, Coğrafya Bölümü, Burdur.

${ }^{b}$ Akdeniz Üniversitesi, Fen Edebiyat Fakültesi, Coğrafya Bölümü, Antalya.

\begin{tabular}{l} 
B I L G I / I N F O \\
\hline Geliş/Received: 23.10.2019 \\
Kabul/Accepted: 26.12.2019 \\
\hline Anahtar Kelimeler: \\
Turizm \\
koruma \\
sürdürülebilirlik \\
Salda Gölüı \\
Burdur \\
Keywords: \\
Tourism \\
Protection \\
Sustainability \\
Salda Lake \\
Burdur \\
\hline
\end{tabular}

*Sorumlu yazar/Corresponding author:

(S. Ceylan) sceylan@ankara.edu.tr

DOI: $19.17211 /$ tcd.637091

\section{Attf/Citation:}

Ceylan, S., Bulut, ì.(2019). Salda Gölü özel çevre koruma bölgesinde turizm baskısı, koruma ve sürdürülebilirlik. Türk Coğrafya Dergisi(73),79-89. DOI: 19.17211/tcd.637091.

\begin{abstract}
ÖZ / ABSTRACT
Araştırmanın amacı, doğal bir turistik yer ve aynı zamanda korunan bir alan olan Salda Gölü'nün ziyaretçi yoğunluğu üzerinden, turizmin doğal alan üzerindeki olası etkilerini belirlemek ve geleceğe dönük olarak koruma ve sürdürülebilirlik temelli çözüm önerilerini sunmaktır. Nitel araştırma yönteminde, görüşme ve gözlem teknikleri kullanılmıştır. 2019 yılında alanda gözlemlerde bulunulmuş, ilgili birim yetkilileri ve diğer paydaşlarla yüz yüze derinlemesine görüşmeler gerçekleştirilmiştir. Ayrıca çalışmada kurumsal raporlardan ve alan araştırmalarından da yararlanılmıştı. Elde edilen tüm veriler betimsel olarak analiz edilerek yorumlanmıştı. Araştırma bulgularına göre, Salda Gölü I. Derece Doğal Sit Alanı olup, ayrıca 2019 yılında Özel Çevre Koruma Bölgesi ilan edilmiştir. Salda Gölüne yılda 700 bine yakın ziyaretçinin turizm ve rekreasyonel amaçlı gelmesi, alan üzerinde bir baskı oluşturmaktadır. Ayrıca gelecek dönemlerde göl çevresi kıyılarının "Millet Bahçesi” olarak yeni bir kullanıma açılacağı dikkate alındığında, hassas bir ekosisteme sahip olan göl alanı üzerindeki ziyaretçi baskısı ve kıyı yapılaşması daha da artacaktır. Turizm ve rekreasyonel faaliyetlerin göl alanındaki baskısı, başta endemik türler olmak üzere göl ve çevresindeki fauna ve flora yaşam alanını etkileyecektir. Ayrıca sahillerin jeolojik yapısı ve kum ekosistemi, insan ve özel araç yoğunluğundan etkilenecektir. Sonuç olarak, Salda Gölü'nün kitle turizmine doğru gidişinin planlama ve sürdürülebilir alan yönetimi çerçevesinde kontrol altına alınması sağlanmalı, alanın sürdürülebilirliği için ziyaretçi kontrolünün yapılması gerekmektedir.
\end{abstract}

The aim of study is to understand possible effects of visitors density in tourism on Salda lake which is natural tourist destination and protected area, and present solutions based on conservation and sustainability as forward-looking. The research was conducted with observation and interview techniques of qualitative method, and evaluation of available second resources. In-depth interview as face-to-face with stakeholders was made in 2019. The obtained data were analysed descriptively. According to the findings of the research the, Salda lake is first degree natural protected area and at the same time, it announced as special environmental protection area in 2019. The lake is under pressure due to visitors which are reaching 700 thousand people annually. Moreover, it was declared a new recreation area as "public garden" in the future. In this case, in the lake area which is a sensitive ecosystem, will increased visitor pressure and coastal construction. Also, habitat of fauna and flora which is living in around the lake, and geological structure will be affected from this situation. As a result, the course of the lake towards mass tourism should be controlled with planning and sustainable area management, and visitor control is done.

\section{Giriş}

Göller, doğa temelli turizm faaliyetlerinin gelişiminde birinci kaynaklar olarak düşünülebilir (Daubariene, 2009: 77). Turistik bir destinasyon olarak bir göl, belirli coğrafi sınırları ile bölgesel bir bütün olup, fonksiyonel kompakt bir bölgedir (Ryhanen, 2003:8). Önemli tatlı su habitatları olan göller, insanlar için önemli bir çekicilik sağlamaktadır (Dokulil, 2014: 81). Diğer bir deyişle göller, bitki ve hayvan toplulukları için önemli bir yaşam alanı olmasının yanı sıra, insanların rekreasyonel faaliyetleri için ayrılan popüler alanlardır. Göller, özellikle ziyaretçi çekmek için, estetik bir öneme sahiptir. Nitekim göller ve sulak alanlar, ilgili birçok şehir ve bölgenin turizm broşürlerinde turist çekicilikleri listesine dâhil edilmektedir. Göller, son zamanlarda spor, eğlence, yüzme, balık tutma gibi rekreasyonel amaçlar için kullanılan mekânlar olmaktadır (Daubariene, 2009: 78). Bu ne- 
enle coğrafi biroluşum olan göllerin büyük bir rekreasyon ve turizm potansiyelinin olduğunun fark edilmesi doğa temelli turizm faaliyetlerinin gelişmesine yol açmıştır (Aydın, 2015: 179). Nitekim bir gölün turizm için uygun olabilmesi için; kolaylıkla erişilebilir olması, gerekli altyapıya sahip olması, iyi bir su kalitesine sahip olması (temiz su) ve gölün su sıcaklığının yüzey sıcaklığına ( $\geq 20$ OC) uygun olması gerekmektedir (Dokulil, 2014: 82).

Göller; tüm dünyada ekoturizm, doğal turizm, boş zaman turizmi için bir kaynak olarak kullanılmakta ve milyonlarca turisti kendisine çekmektedir (Daubariene, 2009: 78). Başta Finlandiya olmak üzere Hollanda, İrlanda ve İzlanda gibi kuzey Avrupa ülkeleri ile $A B D$, dünyada göl turizminin geliştiği başlıca ülkelerdir. Bunlar arasında bin göller ülkesi olarak da nitelendirilen Finlandiya'nın ayrı bir yeri vardır. Diğer turizm olanaklarının nispeten sınırlı olduğu Finlandiya'da göl turizmi çok çeşitli etkinlikleriyle ülkenin büyük sektörlerinden biri durumuna gelmiştir (Lehtolainen, 2003: 1-5; Akpınar ve Akbulut, 2007: 2).

\section{Literatür}

\subsection{Göl Turizmi ve Çevre Koruma}

Coğrafi bir alan olan bir ekosistem, yaşayan bütün organizmaları (insan, hayvan, bitki ve mikroorganizma), onların fiziksel çevresini (toprak, su ve hava) ve onların yaşamını devam ettiren doğal döngüyü içermektedir. Bozulma ile tehdit edilen ekosistemler; alp bölgeleri, yağmur ormanları, sulak alanlar, mercan resifleri gibi ekolojik olarak hassas alanlardır. Bu ekosistemler üzerindeki baskı ve tehditler çok şiddetlidir; çünkü böyle yerler, hem turistler hem de girişimciler için çok çekici gelmektedir (Sunlu, 2003: 265). Hem doğal hem de yapay olan çevrenin kalitesi, turizm için gereklidir (Dokulil, 2014: 82). Bu nedenle, çevresel koruma ve su rezervi konularındaki uzmanlar, Uluslararası Göl Çevre Komitesi'ne (International Lake Environment Committee) ve uluslararası konferanslara katılarak yıllardır sürdürülebilir turizm ve göl ekosisteminin korunması için çeşitli problemlere çözüm sunmaya çalışmaktadırlar (Kurleto, 2013: 92). Türkiye'de de son zamanlarda doğal ve yapay göl alanları üzerine araştırmaların yapıldığı görülmektedir. Bunlar: gölün rekreasyonel potansiyeli (Yiğit, 1994; Birinci vd., 2016; Ceylan, 2006; Bulut ve Ceylan, 2011), göl ekosistemi (Zeybek, 2005), doğal göl alanlarında yüzen adaların korunması ve turistik çekiciliği (Bulut, 2012; Bulut vd., 2008a, 2008b, 2013, 2016) üzerinedir.

Turizmin bir sonucu olarak tatlı su kaynaklarının insan kaynaklı kirlenme ve bozulmaları çok çeşitli olmaktadır. Ziyaretçi sayısı arttğında ve göl çevresi kapasitesinden daha fazla kullanıldığında, turizmin olumsuz etkileri meydan gelmektedir. Nitekim kontrolsüz geleneksel turizm, dünyadaki birçok doğal alan için potansiyel tehdit oluşturmaktadır. Geleneksel turizm faaliyetleri, bir alan üzerinde büyük bir baskı oluşturabilmekte ve toprak erozyonu, kirlilikte artş̧, denize atık boşaltma, doğal habitat kaybı gibi etkilere yol açabilmektedir. Bu tür çevresel durumlar, tehlike altındaki türler üzerindeki baskıyı da artirmaktadır. Ancak göl üzerindeki bu etkiler, gölün alansal büyüklüğü, derinliği ve tipine (doğal-yapay) göre değişebilmektedir. Ayrıca gölün kentsel alana yakınlığı ve kentleşme düzeyi ya da göle gelen ziyaretçi yoğunluğu ve rekreasyonel aktiviteler de göl a- lanlarını çevresel bakımdan etkileyebilmektedir (Tablo 1) (Dokulil, 2014: 81-82).

Tablo 1. Turistik Alanlarda Göl Kullanımın Çeşitli Sonuç ve Etkileri. Table 1. Effects and results of lake using in destination.

\begin{tabular}{|c|c|c|}
\hline Kullanma & Sonuç & Etki \\
\hline Rekreasyon & Ötrofikasyon & Alg çoğalmas1 / yosun artış1 \\
\hline Yüzme & Kirlilik & Oksijen $\left(\mathrm{O}_{2}\right)$ yoğunluğunda azalış \\
\hline Oltayla balık avlama & Çöp & Suyla taşinan hastalıklar \\
\hline Botla dolaşma & Safsızlık / pisletme & Balık ölümleri \\
\hline Su sporlar1 & Erozyon & İç ve dış besin kayb1 \\
\hline Tüple dalış & Rahatsız etme / müdahale & Kiy1 erozyonu \\
\hline Kiy1 aktiviteleri & Gürültü kirliliği & Sesin yayilmas 1 \\
\hline
\end{tabular}

Kaynak: Dokulil, 2014: 83.

Dünya gölleri etrafindaki nüfus artışı, sanayileşme ve turizm, göllerin aşırı kirlenmesine ve bu yüzden göl su kalitesinin ve ekosisteminin bozulmasına neden olmaktadır (ILEC, 2019). Göl üzerindeki turistik aktivitelerin doğrudan etkileri olarak; bakteriyel kirlilik, sedimentlerin (tortu) yeniden sübvansiyonu, dalga etkileri, su bitkilerinin zarar görmesi, yabancı türlerin girişi, balık kompozisyonlarında değişim, atık boşaltma, kıyı yapılaşması (konut, işletme, marina, iskele), çöp, kıyı tahribat,, kıyı boyunca vejetasyon değişimi ve doğal yaşamın rahatsız edilmesi durumları sıralanabilir (Dokulil, 2014: 83). Abercrombie (2019), turizm ve rekreasyonel faaliyetlerin ekosistemler üzerinde hem doğrudan hem de dolaylı etkileri olabildiğini belirtmektedir. Göllerde, akarsularda, sulak alanlarda ve nehir kıyılarında gerçekleşen turizm ve rekreasyon faaliyetleri su ortamını olumsuz etkileyebilmektedir. Nitekim bu alanlarda yapılan balıkçılık ve avlanma, arazi taşıtları ile dolaşma, karayolu taşıtlarının yoğunluğu, tekne motorlarının akaryakıt sızıntıları ve ziyaretçi nüfusunun alanda doğru bir şekilde yönetilememesi gibi durumlar su ekosistemleri üzerindeki potansiyel etkiyi artırmaktadır. Bu araştırma ise, daha önceki çalışmalardan farklı olarak göl-turizm ilişkisi temelinde ele alınmış olup, turizmin göl alanına etkisi ve nasıl korunabileceği üzerine yapılmıştır. Nitekim bu çalışmanın, doğal bir turistik çekicilik olan Salda Gölü'nün turizm baskısı karşısındaki durumunu anlamak bakımından literatürde önemli bir boşluğu dolduracağı öngörülmektedir.

\section{Yöntem}

Salda Gölü Doğal Sit Alanı́nda görülen ziyaretçi yoğunluğu, alanın doğal ekosistemi üzerindeki ziyaretçi baskısını ve etkilerini artırmaktadır. Bu bağlamda araştırmanın amacı, ziyaretçi yoğunluğu temelinde, göl alanında koruma ve sürdürülebilirlik temelli bir durum tespiti yapmak ve turizmin doğal alan üzerindeki etkilerini anlamak ve buna yönelik çözüm önerileri sunmaktır. Araştırmada nitel araştırma yöntemi kapsamında, 2019 yılında gözlem ve görüşme teknikleri uygulanmış; ayrıca çalışmada ikinci kaynaklardan da yararlanılmıştır. Görüşme yapılan kişiler amaçlı örneklem yöntemine göre belirlenmiş; katılımcıların konu hakkında ilgili ve bilgili kişiler olmasına dikkat edilmiştir. Yüz yüze yapılan derinlemesine görüşmeler yarı yapılandırılmış görüşme formları üzerinden gerçekleştirilmiştir. Görüşme yapılan kişi sayısı, nitel verilerde doygunluğa (verilerin birbirini tekrar etme durumu) ortaya çıkıncaya kadar devam etmiştir. Ayrıca alandaki farklı paydaş gruplarla görüşülerek, görüşme verilerinde bir çeşitlilik sağlanmak istenmiştir. Böylece farklı paydaş grupların aynı konu hakkındaki görüşlerinin benzer ve farklı yanları ortaya koyulmuştur. Araştırma alanında 2019 yılında gözlemlerde bulunulmuş, turizmin olası etkileri 
yerinde gözlemlenmiştir. Elde edilen tüm bulgular betimsel olarak (alıntılama yapılarak) analiz edilerek yorumlanmıştır. Araştorma soruları:

- $\quad$ Salda Gölü doğal kaynak değerleri yeterince korunmakta mıdır?

- $\quad$ Turizm ve rekreasyonel faaliyetler göl alanı üzerinde nasıl bir baskı oluşturmaktadır?

- Yerel yönetimlerin alanın korunması ve sürdürülebilirliği konusundaki önlemleri yeterli midir?

- $\quad$ Alanın "millet bahçesi" olması durumunda, ÖçK Bölgesi ilan edilen göl alanı ekolojik bakımdan nasıl etkilenecektir?

- $\quad$ Ziyaretçi yoğunluğu göl alanı ve çevresinde nasıl bir etki oluşturmaktadır?

\section{Araştırma Alanı}

Araştırma alanı olan Salda Gölü, Akdeniz Bölgesi'nde yer almakta olup Antalya Bölümü’nün Göller yöresinin Tefenni-Burdur Oluğu Alt Yöresi içinde kalmaktadır. İdari olarak ise, Burdur iline bağı Yeşilova ilçesinin idari sınırları içerisinde kalmaktadır. Göl çevresinde Salda, Doğanbaba ve Niyazlar köy yerleşim alanları ve Yeşilova ilçesine bağlı Kayadibi Mahallesi bulunmaktadır (Şekil 3).

\subsection{Ekolojik Alan Olarak Salda Gölü}

Salda Gölü tektonik kökenli bir göl olup Neojen sonunda oluşmuş, daha sonra tektonik hareketlere maruz kalmış ve bu tektonik hareketler sonucu göl çevresinde, tedricen alçalan kıyılar ve basamaklar halinde dik kıyılar meydana gelmiştir. Alçak kıyılar aynı zamanda birikme ve bataklık sahalara da tekabül etmektedir (Güney, 2004: 238; Orman ve Su İşleri Bakanlığı, 2013: 29). Salda Gölü, yaklaşık 6,8 km eninde, 9.186 km uzunluğunda bir tektonik çukurun üzerine yerleşmiş kapalı bir havzanın içerisinde yer almaktadır (Çevre ve Şehircilik Bakanlığı, 2019a). Salda Gölü yüzey alanı yaklaşık 45 km2, ortalama su derinliği $80 \mathrm{~m}$, ortalama su derinliği $185 \mathrm{~m}$ olan bir göldür (Kazancı vd., 1999: 5; Güney, 2004: 238; Kapan, 2016: 700).

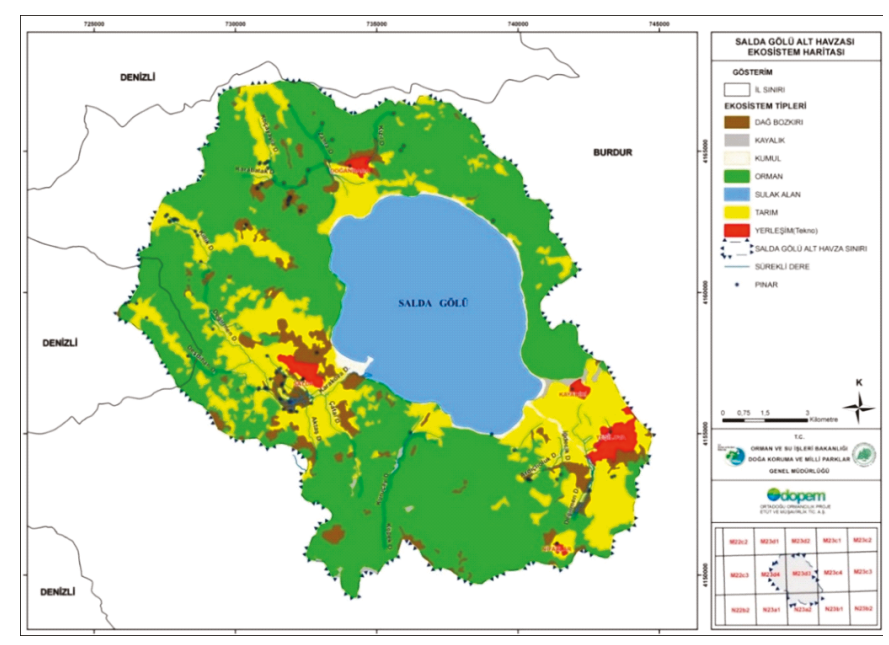

Şekil 1. Salda Gölü Ekosistem Haritası (Orman ve Su İşleri Bakanlığı, 2013). Figure 1. Ecosystem Map of the Salda Lake.
Salda Gölü, CO2'in doğal yollarla depolanmasına dair önemli bir örnek teşkil etmektedir (Kazancı vd., 2004; Kaiser vd., 2016). Gölün su bütçesi önemli oranda buharlaşma (evaporasyon) etkisi altındadır. Yüzey akıntısı olmayan gölün ana beslenimi meteorik sularla sağlanmaktadır (Balcı vd., 2018: 21). Göl çevresinde yapılan araştırmalar (Braithwaite ve Zedef, 1996; Russel vd., 1999; Kazancı vd., 2004), göl suyunun kimyasının meteorik sular ile arazinin jeolojik yapısından kaynaklandığını belirlemiştir. Gölün litolojik yapısının büyük bir bölümünü kapsayan Üst Kretase yaşlı Yeşilova ofiyolitlerine ait kısmen serpantinitleşmiş harzburjit ile yer yer görülen dünit mostraları ve bunlardan türeyen sedimanların etkileşimi göl suyunu etkileyen litolojik unsurlardır (Balcı vd., 2018: 21). Göl suyunun yüksek alkali değerine sahip $(\mathrm{pH}>9)$ suyu, güncel manyezit oluşumlarının sonucu olan bembeyaz kumsalları ve turkuaz rengi gölün önemini artırmaktadır (Akgül vd., 2017).

Deniz seviyesinden 1193 metre yüksekte yer alan ve yer yer 185 metre derinliğe sahip olan tektonik gölün suyunun berrak olması dikkati çekmektedir (Güney, 2004: 238). Beyaz kumsalı ve "Mars gezegeni" görünümlü jeolojik yapısı ile dikkati çekmektedir (Burdur il Kültür ve Turizm Müdürlüğü, 2014). Salda Gölü aynı zamanda bir sulak alan olması nedeniyle, flora ve fauna bakımında oldukça zengin bir biyoçeşitliliği bünyesinde intiva etmektedir. Alanda tespit edilen 20 bitki türünden 5 'i (Bolanthus thymoides, Trigonella rostrata, Amelanchier parviflora, Verbascum dudleyanum, Verbascum flabellifolium) Türkiye florasına göre endemiktir. Farklı zamanlarda alanda yapılan araştırmalarda, 8 iç su balığı, 5 iki yaşamlı, 27 sürüngen, 69 kuş, 5 memeli olmak üzere toplam 114 omurgalı türü tespit edilmiştir. Ayrıca alanda 69 kuş türü gözlenmiştir. Bu türlerden 54'ü yerli ve yaz göçmeni, 15 'i ise kış göçmenidir. . Alan kapsamında IUCN (Uluslararası Doğa Koruma Birliği) kriterlerine göre tehlikede (endangered) kategorisine dâhil türler (Phalarocorax aristotelis, Ardea purpurea, Ardea alba, Falco tinnunculus, Athene noctua, Phoenicurus ochruros, Oriolus oriolus, Sylvia atricapilla, Ficedula albicollis ve Sylvia communis) yer almaktadır. Ayrıca kritik (critically) kategorisine dâhil Alcedo atthis türü bulunmaktadır (Çevre ve Şehircilik Bakanlığı, 2019a, 2019b). Bu tespitler, alanın orman ekosistemi bakımından ne kadar hassas bir bölge olduğunu ortaya koymaktadır. Aydın vd.'ye (2019) göre, Salda Gölü'nün ÖçK bölgesi olmasıyla beraber, biyoçeşitlilik araştırmalarına ve planlama çalışmalarına başlanılmıştır.

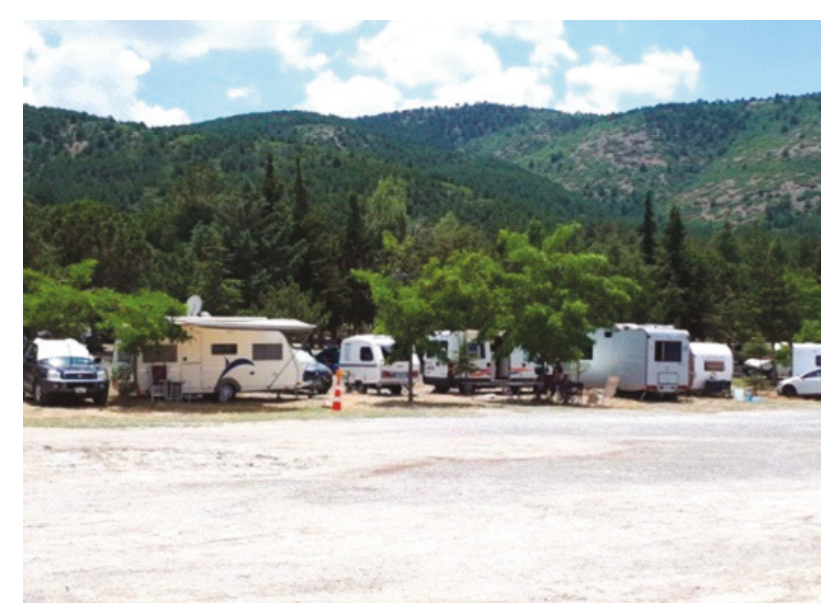

Foto 1. Salda Gölü Orman Ekosisteminden Görseller (Ceylan (C). Photo 1. View from forest ecosystem of the Salda lake. 


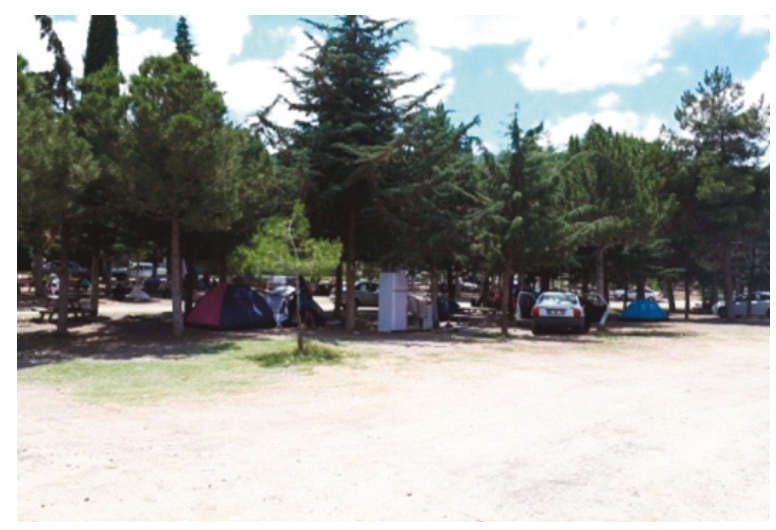

Foto 2. Salda Gölü Orman Ekosisteminden Görseller (Ceylan@)).

Photo 2. View from forest ecosystem of the Salda lake.

Araştırma alanı; jeolojik yapısı ve sahip olduğu endemik türleri ile IUCN’nin “Önemli Doğa Alanı (ÖDA)" ve “Önemli Kuş Alanı” kriterlerini sağlamaktadır. Göl havzasının IUCN tarafindan koruma altına alınan kritik türlere ev sahipliği yapması, uluslararası ve ulusal düzeydeki önemini artmaktadır. Salda Gölü ve çevresinde yapılan çalışmalar, dünyada Mars gezegeninin yüzey özelliklerini (magnezyum yüklü beyaz kayalar) taşıyan dünyadaki iki bölgeden birisi olma özelliğine sahip olduğunu göstermiştir. Bu özelliği, alanın kumul ekosisteminin önemini göstermektedir. Ayrıca Salda Gölü'nün temiz suyu, oligotrofik özellikte, az tuzlu ve yüksek alkalinite özellik göstermesi, gölün biyoçeşitliliği ve üretkenliği konusunda belirleyici etken olmaktadır. Ayrıca bu durum, ekosistem dengesi hala bozulmamış bir göl olma özelliğini sürdürdüğünü göstermektedir (Çevre ve Şehircilik Bakanlığı, 2019a, 2019b). Salda Gölü ve çevresinin ekosistemi; sulak alan, dere, kumul, ağaçlık, orman, dağ bozkırı, kayalık, tarım ve tekno (yerleşim) ekosistemlerinden oluşmaktadır (Foto 1, 2, 3; Tablo 2).

Tablo 2. Salda Gölü ve Çevresinin Ekosistem Tipi ve Büyüklüğü.

Table 2. Ecosystem type and size of the Salda lake.

\begin{tabular}{|c|c|c|c|c|}
\hline Ekosistem Tipi & $\begin{array}{r}\begin{array}{r}\text { Büyüklüğg̈ } \\
\text { (ha) }\end{array} \\
\end{array}$ & $\begin{array}{r}\text { Yüzde } \\
\%\end{array}$ & Sulak Alana Uzaklığı & Açıılama \\
\hline Sulak Alan Ekosistemi & $4.508,46$ & 20,94 & Bitişik & $\begin{array}{l}\text { Bölgenin en önemli ekosistemi: Salda } \\
\text { Gölü ve dereler }\end{array}$ \\
\hline Kumul Ekosistemi & 282,16 & 1,31 & Bitisisik & Göl kenar kıyllar1 \\
\hline Dağ Bozkiri Ekosistemi & $1.138,65$ & 5,29 & Havzanın genelinde & Seyrek bitki örtü alanları \\
\hline Orman Ekosistemi & $11.007,93$ & 51,13 & $\begin{array}{l}\text { Bitisikik ve havzanin } \\
\text { genelinde }\end{array}$ & $\begin{array}{l}\text { Kizılcam, karaçam, ardıc, sedir ve çalı } \\
\text { formasyonu }\end{array}$ \\
\hline Kayalık Ekosistemi & 105,50 & 0,49 & $\begin{array}{l}\text { Bitişik ve havzanın } \\
\text { genelinde }\end{array}$ & Göl kenarı kyyları \\
\hline Tarmm Ekosistemi & $4.168,63$ & 19,36 & $\begin{array}{l}\text { Bitisikik ve havzanin } \\
\text { genelinde }\end{array}$ & Göl çevresindeki tarım alanları \\
\hline $\begin{array}{l}\text { Tekno (yerlesim) } \\
\text { Ekosistemi }\end{array}$ & 318,50 & 1,48 & $\begin{array}{l}\text { Havzaning genelinde ve } \\
\text { dağınık }\end{array}$ & $\begin{array}{l}\text { Yessilova ilçe merkezi, Salda beldesi, } \\
\text { Kayadibi, Doğanbaba ve Nivazlar kôyl }\end{array}$ \\
\hline
\end{tabular}

Kaynak: Orman ve Su İşleri Bakanlığı, 2013.

Gölün su deviyesi 1958-69 periyodunda sürekkli yükselmiş, ancak 1970-77 döneminde görülen kuraklığa bağlı olarak göl su seviyesi sürekli düşüm göstermiştir. Nitekim 1978 yılında su seviyesi, $47 \mathrm{~cm}$ eşel seviyesine düşmüştür. 1985-99 yılları arasındaki su seviye düşümleri, kurak dönem şartları ve göl çevresindeki sahalarda yapılan yeralt suyu çekimlerine bağlı olarak gelişmiştir (Kazancı vd., 1999: 36). Günümüzde göl su seviyesinin yılda yaklaşık $50 \mathrm{~cm}$ değişmesinin sebebi olarak, yeraltı suyunun sulama amaçlı olarak kullanılması, buharlaşma ve göl çevresindeki karstik akiferler gösterilmiştir (Balcı vd., 2018: 21).
İklimsel değişimler ve havzanın hidrografik yapısının kontrolsüz bir şekilde kullanılması durumunda yaşanacak olan su seviye değişimleri, gölün sulak alan ekosistemini olumsuz etkileyebilecektir.

Havza ekosistemine arazi kullanımı üzerinden bakıldığında ise; arazi kullanım kabiliyeti sınıflandırmasına göre, Salda Gölü en fazla 10643,97 ha $(\% 49,44)$ ile VII. sınıf arazilerden oluşmaktadır (Şekil 2). Bu arazileri sırasıyla 1857,3 ha $(\% 8,63)$ ile VI. sınıf arazi, 1840 ha $(\% 8,55)$ ile II. sınıf arazi, 996,62 ha $(\% 4,63)$ ile IV. sınıf arazi, 893,26 ha $(\% 4,15)$ ile III. sınıf arazi, 352 ha $(\% 1,64)$ ile I. sınıf arazileri takip etmektedir. Eğim ve erozyon zararı ile toprak yetersizliği alanda görülen toprak sorunlarını oluşturmaktadır (Orman ve Su İşleri Bakanlığı, 2013). Göl çevresindeki yerleşmelerin hayvanlarını bilinçsiz bir şekilde otlatma durumu da bu toprak sorununu olumsuz etkileyebilecektir.

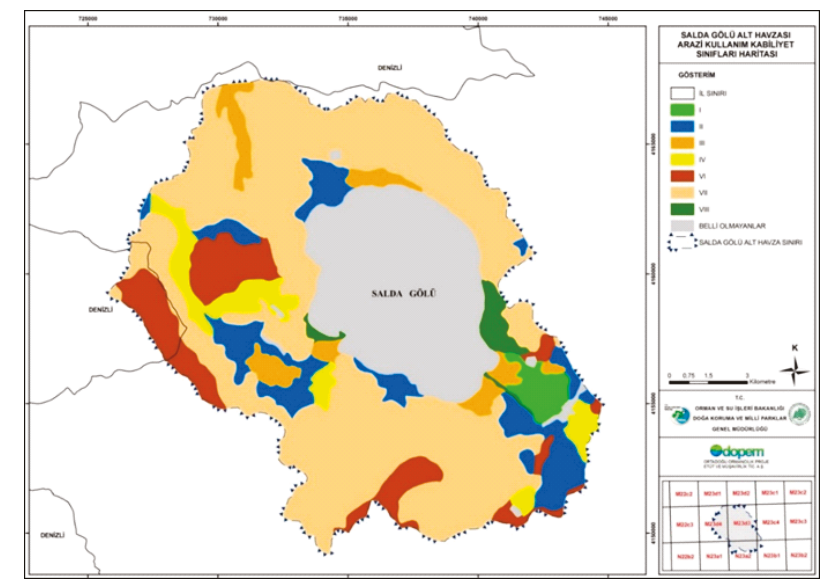

Şekil 2. Salda Gölü Arazi Kullanım Sınıflandırması (Orman ve Su İşleri Bakanlığı, 2013).

Figure 2. Land using classification of the Salda lake

\subsection{Korunan Alan Olarak Salda Gölü}

Salda Gölü ve çevresi (47 km2), 1989-1992 yıllarında I. Derece Doğal Sit Alanı, bazı kesimleri ise II. Derece Doğal Sit Alanı olarak tescil edilerek koruma altına alınmıştır. Araştırma alanının bir kısmı 2011 yılında Tabiat Parkı ilan edilmiştir. Salda Gölü, 2006 yılında Bakanlar Kurulu kararı ile "turizm merkezi" ilan edilmiştir; ancak 2019 yılı 824 Sayılı Cumhurbaşkanı Kararı ile "Özel Çevre Koruma Bölgesi" (ÖÇK Bölgesi) olarak tespit ve ilan edildikten sonra gölün "turizm merkezi" statüsü kaldırılmıştır.

Tablo 3. Salda Gölü Sorumlu Kurum ve Birimler

Table 3. Responsible Public Institutions from the Salda lake.

\begin{tabular}{|c|c|c|c|}
\hline Koruma ve Turizm Bölgeleri & İlan Yllı & Yetkili Kurum & Yetkili Birim \\
\hline $\begin{array}{l}\text { Salda Gölü I. ve II. Derece Doğal Sit } \\
\text { Alanı }\end{array}$ & 1989 & $\begin{array}{l}\text { Çevre ve Şehircilik } \\
\text { Bakanlı̆ğ }\end{array}$ & Çevre ve Şehircilik II Müdürlüğü \\
\hline Salda Gölü Turizm Merkezi* & 2006 & $\begin{array}{l}\text { Kültür ve Turizm } \\
\text { Bakanlloğ }\end{array}$ & Kültür ve Turizm İ Müdürlüğü \\
\hline Salda Gölü Tabiat Park1 & 2011 & $\begin{array}{l}\text { Orman ve Su İşleri } \\
\text { Bakanlığ }\end{array}$ & $\begin{array}{l}\text { Doğa Koruma ve Milli Parklar Şube } \\
\text { Müdürlüğü }\end{array}$ \\
\hline $\begin{array}{l}\text { Salda Gölü Özel Çevre Koruma } \\
\text { Bölgesi }\end{array}$ & 2019 & $\begin{array}{l}\text { Çevre ve Șehircilik } \\
\text { Bakanlığ1 }\end{array}$ & Çevre ve Şehircilik İ Müdürlüğü \\
\hline
\end{tabular}

Kaynak: Orman ve Su İşleri Bakanlığı, 2013.

Salda Gölü doğal sit alanı 5898 ha iken, ÖçK bölgesi kapsamında 8474 ha'a çıkartılmıştır. Doğal sit alanı dışında, ÖÇK bölgesi olarak koruma altına alınan alan ise 29.500 ha'dır. Başka bir ifadeyle, ÖçK ile birlikte korunan alan genişliği 4.400 ha'dan 29.500 ha'a çıkartımıştır (Aydın vd., 2019). 


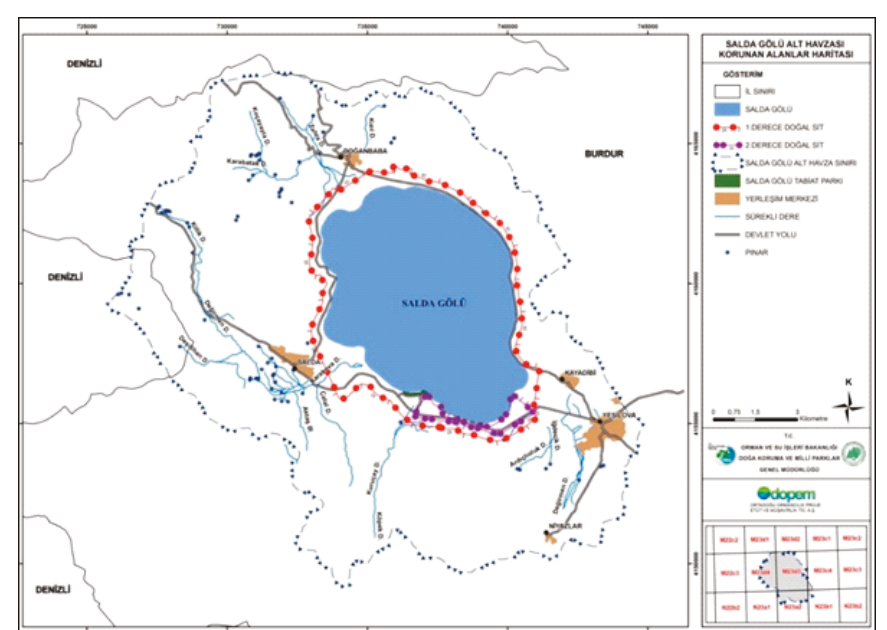

Şekil 3. Salda Gölü Korunan Alan Haritası (Orman ve Su İşleri Bakanlığı, 2013). Figure 3. Map of protected area of the Salda lake.

Salda Gölü havzasının turizm ve rekreasyon amaçlı kullanılan alanının bir kısmı, "doğal sit alanını" içerisinde yer almaktadır (Şekil 3). Başka bir deyişle, alanda gerçekleştirilen turizm ve rekreasyonel faaliyetler (yüzme, göl kenarı yürüyüş vb.), Salda Gölü sulak alan koruma bölgeleri içerisinde kalmaktadır (Tablo 4). Bu nedenle alana gelen ziyaretçi yoğunluğunun doğal sit alanı üzerinde bir baskı oluşturma riski bulunmaktadır.

Tablo 4. Salda Gölü Koruma Bölgeleri

Table 4. Protected areas of the Salda lake.

\begin{tabular}{lcc}
\hline Koruma Bölgeleri & Alan (ha) & Yüzde \% \\
\hline Sulak Alan Bölgesi & $4.522,03$ & 21,80 \\
Mutlak Koruma Bölgesi & 83,06 & 0,40 \\
Ekolojik Etkilenme Bölgesi & 330,37 & 1,60 \\
Tampon Bölge & $15.799,15$ & 76,20 \\
\hline Toplam & $\mathbf{2 0 . 7 3 4 , 6 1}$ & $\mathbf{1 0 0}$
\end{tabular}

Kaynak: Orman ve Su İşleri Bakanlığı, 2013.

IUCN kriterlerine göre hassas bir ekosistem olan Salda Gölü Doğal Sit Alanı, 14.03.2019 tarihinde Cumhurbaşkanı Kararı ile "Özel Çevre Koruma Bölgesi" olarak tespit ve ilan edilmiştir. Ayrıca 2019 yılı içerisinde göl alanının "Millet Bahçesi ve Millet Bahçesine Ait Donattlar İle Alt Yapı ve Çevre Düzenlemesi” şeklinde kullanıma açılacağı üst makamlarca belirtilmiştir. Tabiat Varlıkları Koruma Genel Müdürlüğü yetkilileri tarafindan Nisan 2019 döneminde Burdur'da bir çalışma yapılmış ve Salda Gölü ve çevresinde incelemelerde bulunulmuştur. Gerçekleştirilen toplantılar ve alandaki incelemeler ile göl çevresinde "Millet Bahçesi Projesi" kapsamında yürütülecek kıyı düzenleme projeleri belirlenmiştir (Orman ve Su İşleri Bakanlığı, 2017a, 2017b; Çevre ve Şehircilik Bakanlığı, 2019b). Çevre ve Şehircilik Bakanı Murat Kurum; alanda çevre düzenlemesi yaptıklarını, kıyının ilk $500 \mathrm{~m}$. bandında hiçbir yapı ve geçici barınağın (çadır, konteynır vb.) yapılamayacağını, çarpık yapıları (konteynır, baraka, kıl çadır) yıktıklarını, bunların yerine geçici (ahşap) yapıları koyduklarını ve bu yapılarda vatandaşların günlük ihtiyaçlarını (duş, wc, kafeterya, giyinme-soyunma vb.) giderebildiklerini belirtmiştir. Ayrıca Salda Gölü'nün korunması ve turizm amaçlı işletilmesi için, 2019 yılında alana 2 milyon TL kaynak aktardıklarını belirtmiştir (Web 1).
Antalya Kültür ve Tabiat Varlıklarını Koruma Bölge Kurul Müdürlüğü’nün 2010 yılında yapmış olduğu (119 sayılı) toplantida, Burdur îl Çevre ve Orman Müdürğü’nün talebi doğrultusunda, I. Derece Doğal Sit Alanı olan “Salda Gölü’ndeki mevcut kirliliğin izlenmesi" faaliyeti kapsamında, kirlilik yükünün belirlenmesi amacıyla Mobil Su Kirliliği Ölçüm Aracı ve Fiber Tabanlı Numune Alma Botu tarafindan gölden numune alma kararı alınmıştır (Kültür ve Turizm Bakanlığı, 2013). Çevre ve Şehircilik Bakanlığı'nın (2019a) da yaptı̆̆ incelemelerde Salda Gölü'nün yoğun ziyaretçi aldığı ve bu durumun da alanda antropojenik baskıyı artırdığı tespit edilmiştir. Göl alanında turizm kaynaklı görülen ziyaretçi baskısını, "planlama" ve "kontrollü kullanım" ile en aza indirebilmek için, Bakanlık bünyesinde alanda bir takım toplantıların gerçekleştirildiği belirlenmiştir.

\subsection{Salda Gölü’nde Turizm ve Rekreasyon}

Salda Gölü mesire yeri 11 Temmuz 2011 tarihinde "Tabiat Parkı" (12 ha) ilan edilmiştir (Orman ve Su İşleri Bakanlığı, 2013). Salda Gölü'nde turizm ve rekreasyonel amaçlı üç plaj alanı bulunmaktadır: Beyaz Adalar Plajı (Salda Köyü), Doğanbaba Plajı ve Belediye Halk Plajı (Kayadibi Mahallesi). "Türkiye'nin Maldivleri" olarak nitelendirilen Salda Gölü, bu özelliğini Salda Köyü giriş kısmında yer alan beyaz kum renginden almaktadır (Foto 3,4$)$. Alanın günümüz turizminde pazarlamasında ve markalaşmasında "Türkiye'nin Maldivleri" etiketi öne çıkmaktadır (Burdur ì Kültür ve Turizm Müdürlüğü, 2014).

Gölün Yeşilova Belediyesi tarafindan işletilen “Belediye Halk Plajı́nda çadır ve karavanlarla kamp yapılabilmekte, piknik, gezinti, yüzme, kil-çamur banyosu gibi rekreasyonel aktiviteler gerçekleştirilebilmektedir. Ancak alan ÖÇK bölgesi ilan edildiği için, göl üzerinde tekne, bot ve yelkenli kano faaliyetlerine izin verilmemektedir. Ayrıca Salda Gölü ve çevresinde 34 km'lik bisiklet turizm rotası, göl manzaralı (Eşeler Dağı) yayla turizm alanları, kış turizmi (Salda Kayak Merkezi), foto safari (kuş gözlemciliği), su altı dalış ve atlı yürüyüş gibi diğer rekreasyonel aktiviteleri yapma potansiyeli de bulunmakta; ancak henüz bu faaliyetler alanda gerçekleştirilmemektedir. Göle giriş ücretleri, Belediye Halk Plajı'nda Yeşilova Belediyesi tarafindan; Salda Köyü girişinde ise Yeşilova Kaymakamlığı tarafindan alınmaktadır. Ancak alanın ÖçK bölgesi olarak ilan edilmesiyle, 2019 Ekim döneminden sonra Belediyenin plaj işletme izni kaldırılmıştır.

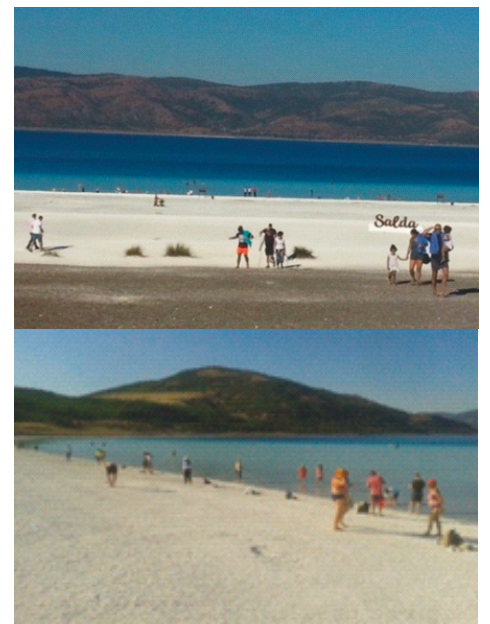

Foto 3. Salda Gölü Beyaz Adalar Plajından Görseller (Ceylan @)).

Photo 3. Views from white islands beach of the Salda lake. 

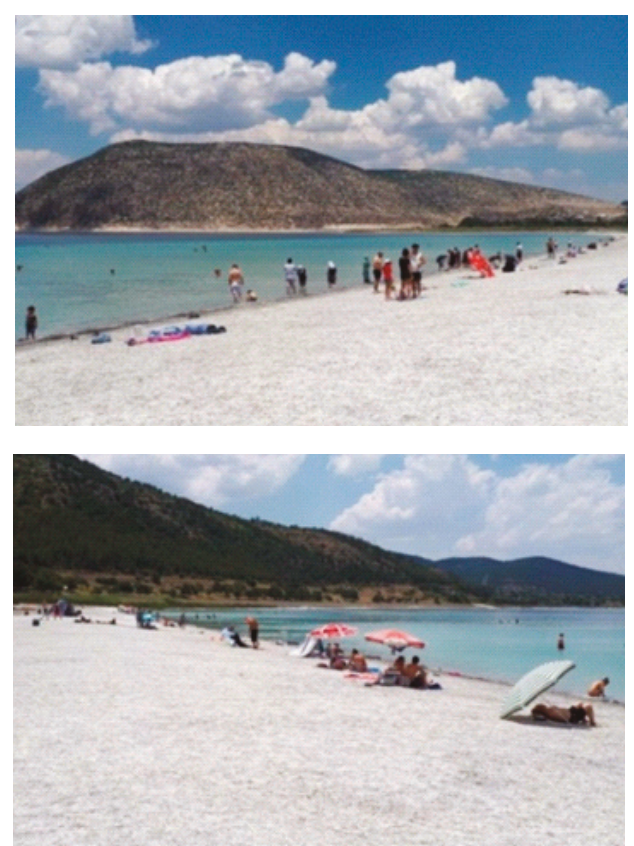

Foto 4. Salda Gölü Belediye Halk Plajından Görseller (Ceylan (C)). Photo 4. Views from municipality public beach of the Salda lake.

\begin{tabular}{llrr}
\hline Turizm Yeri & & 2018 & \multicolumn{1}{c}{$2019 *$} \\
\hline \multirow{4}{*}{ Salda Gölü } & Beyaz Adalar Plaj1 & 292.000 & 338.000 \\
\cline { 2 - 4 } & Salda Gölü Tabiat Park1 & 97.730 & 25.504 \\
\cline { 2 - 4 } & Salda Gölü ve Doğanbaba Plaj1 & 300.000 & 34.935 \\
\cline { 2 - 4 } & Toplam & $\mathbf{6 8 9 . 7 3 0}$ & $\mathbf{3 9 8 . 4 3 9}$ \\
\hline
\end{tabular}

Kaynak: Burdur i̇ Kültür ve Turizm Müdürlüğü, 2019b.

Salda Gölü’ne 2018 yılında yaklaşık 690 bin ziyaretçinin geldiği, 2019 yılının ilk altı ayında ise yaklaşık 400 bin ziyaretçinin göl alanını turizm ve rekreasyonel amaçlı olarak kullandığı görülmektedir (Tablo 5). Salda Gölü Doğal Sit Alanı'nın ziyaretçi yoğunluğunun göz önüne alınarak, alanın ekolojik hassaslığının gözetilmesi ve kitle turizmine yönelik bir yönetim anlayışından uzaklaşılması gerekmektedir. Alanın korunması öncelikli bir durum haline getirilmeden ve göl ile ilgili bir "alan yönetim planı" yapılmadan ziyaretçi sayısının yerel yönetimlerce "bir milyona çıkarılma düşüncesi", alanın orman, kumul ve diğer ekosistemlerinin sürdürülebilirliğini ortadan kaldıracaktır.

\section{Bulgular}

Görüşme yapılan katılımcılara ilişkin bazı bilgiler Tablo 6'da sunulmuştur. Paydaşların Salda Gölü ile ilgili görüşleri 4 kategorik başlık altında analiz edilerek temalaştırılmıştır.

Tablo 6. Görüşmeye Kattlan Paydaş Gruplara İlişkin Bilgiler. Table 6. Some information about interviewed stakeholders.

\begin{tabular}{|c|c|c|c|}
\hline Kod & Cinsiyet & İși & Paydaș \\
\hline K1 & Erkek & Kamu Yöneticisi & Burdur Ili Doğa Koruma ve Milli Parklar Șube Müdürü \\
\hline $\mathrm{K} 2$ & Erkek & Kamu Yöneticisi & Burdur İli Çevre ve Şehircilik Muduru \\
\hline $\mathrm{K} 3$ & Kadin & Kamu Yöncticisi & Burdur Îli Kültür ve Turizm Müdürü \\
\hline K4 & Frkek & Fsnaf & Kayadibi Mahallesi yerel halkı, Belediye Halk Plajinda Ișletmeci \\
\hline K5 & Erkek & Emekli & Salda Köyü yerel halkı \\
\hline K6 & Kadın & Esnaf & Salda Köyù yerel halkı, göl kenarında pazarcı \\
\hline K7 & Erk & Esnaf & Salda Köyiu yerel halkı, göl kenarnnda pazarcı \\
\hline K8 & Kadın & Esnaf & Salda Köyli yerel halkı, göl kenarnnda pazarcı \\
\hline K9 & Kadın & İșci (İSKUR) & Salda Köyü yerel halkı, göl kenarnda Kaymakamlı̆a bağlı ișletmelerde çalıșan \\
\hline K10 & Erkek & Muhtar & Salda Köyil Muhtarı \\
\hline K11 & Erk & Muhtar & Kayadibi Mahallesi Muhtarı \\
\hline $\mathrm{K} 12$ & Erkek & Kamu Yöneticisi & Yesilova Beledivesi Baskanı \\
\hline
\end{tabular}

\subsection{Kategori 1: Ekolojik Duruma İlişkin Görüşler}

Salda Gölü su seviyesinin buharlaşma, göl çevresindeki karstik akiferler, yeraltı suyunun sulama amaçlı kullanılması nedeniyle yılda yaklaşık $50 \mathrm{~cm}$ değiştiği (Balcı vd., 2018: 21) belirlenmiştir.
Görüşme yapılan paydaşların da bu seviye değişim durumuna ilişkin tespit ve gözlemleri olmuştur:

"Göl her sene en az 5 metre çekiliyor. Her yıl en az 5 metre. Bazı yıllar 10 metre 15 metre. Bu gölün tekrar seviyesinin artacağını düşünmüyorum, çünkü eskisi gibi ne kar yağıyor ne yağmur. Şimdi kar yağsa inanırım (gölün su seviyesinin artacağına). ... Ama eskisi gibi kar yok artık. Yarışlı Gölü kurudu. (K4, İşletmeci, Erkek)."

"Son 20 yıl içerisinde göl su seviyesinde azalma var, 3-4 metre. Bu azalma biraz daha devam ederse, göl kenarındaki kıyı renk değişimleri kaybolacak ve tek düze bir renk halini alacak. Kıyıdaki renk değişimi renk geçişini göremeyeceğiz. Bununla ilgili de ciddi önlemlerin alınması gerektiğini düşünüyorum... (K1, Doğa Koruma ve Milli Park Şube Müdürü, erkek)."

Turizm ve rekreasyonel amaçlı gelen yoğun ziyaretçi nedeniyle gölün bir takım çevresel sorunlarla karşı karşıya kaldığı da görülmektedir:

"...Şu sazlıkların içinde çok afedersin kadın pedi var, şort var, çöp var. Aklına ne geliyorsa var. ...Bu göl inanılmaz derecede şu an kirlidir, kim ne derse desin. Günlük diyelim, buraya 15 bin kişi geliyor, bunların 5 bin tanesi göle giriyordur. En az bin tanesi de çok özür dilerim, buraya işiyor. 200 gramdan işese, 5 bin tanesi 10 ton yapıyor ya. Günlük 10 ton. 10 ton amonyak demektir bu. ... Ben şimdi kumsaldayım, (tuvalet için) $1 \mathrm{~km}$ ileri ben yürüyeceğim ya. Restorantların üzerinde tuvaletler, orası da kumsala $1 \mathrm{~km}$. Seyyar tuvalet yapın dedim, elli kere yalvardım, yapmadılar. (K4, Işletmeci, Erkek)."

"il özel idare, bu gölün temizliği ve idaresinin hakkından nasıl gelecek? Çok merak ediyorum. Bakın, belediyeler bu konuda uzmandır. En kötü işletilen bir belediye bile, çevre şehircilikten, özel idareden güzel yapar bu işi. Bu iş, muhtarlığın yağacağı, özel idarenin yağacağı bir iş değil. Tabiat parkından Karaoluk'a kadar olan yerin biz temizliğini yapıyoruz. Belediye Halk Plajı'nda günde üç defa temizlik yaptik (K12, Yeşilova Belediye Başkanı, erkek)."

\subsection{Kategori 2: Korumaya İlişkin Görüşler}

Salda Gölü ÖÇK Bölgesi'nin göl çevresindeki köy yerleşim alanlarını da içine alacak şekilde geniş tutulması, alanda yapılaşmaya yönelik birtakım (yapı izni, ruhsat vb.) idari sıkıntlara neden olduğu ve bu durumun yerel halk tarafindan da eleştirildiği görülmüştür.

"ÖÇK çok geniş bir alanı kapsıyor. Çevresindeki köylerde insanlar kafasına göre öyle bina yapamıyor. (K2, il Çevre ve Şehircilik Müdürü, Erkek)."

"Biz burasının turizmin içerisinde olmasından memnunuz. Buranın ÖÇK olduğundan memnunuz ama ÖÇK'nın alanı çok geniş. Keşke biraz kısa olsaydı. Bizim sıkıntımız o. Neden? Biz burayı koruyamayız. Devlet koruyacak. Halk olarak burası korunmayacak. Iki iki daha dört. (K10, Salda Köyü Muhtarı, erkek)." 
"...Özel Çevre Koruma köyü de kapsıyor, çok ileriye kadar, 7 km çapında. ... Tarım arazilerinin ticari amaçlı kullanılmasına izin verilmiyor. Tarım amaçlı kullanılmasına izin veriliyor. ...Şimdi köylü pansiyonculuk yapmak istiyorlar mesela. Ama inşaat yasak olduğu için başlayamıyorlar. ...Şimdi Özel Çevre Koruma olduğu için inşaatlarda da yasak tarım arazileri üzerine bir şey yapmak da yasak. Her şey yasak yani. Mesela 30 yıllık bir bağ evi vardı. Onlara falan komple ceza kesildi. Onlar falan yıkıldı hep. Komple yıktırıldı. ...(Özel Çevre Koruma'dan dolayı) köylü tepkili, kendi arazisine bir şey yaptiramıyor. ... Fotoğraflıyorlar, bilmem ne yapıyorlar, cezayı kaktırıyorlar. ...Cezayı neyle ödeyeceğim ben. ...Kayadibi köyü değil, her taraf tepkili. Özellikle belediye, (arazi) elimden gitti diye tepkili... (K4, işletmeci, erkek)."

"Salda Gölü, ismini bizim köyden aldı. Burası (Salda Köyü Plajı), eski köy yeri. Biz buraya hep köy yeri derdik. Köy yeri mevkisi derdik. Ama elimizden aldılar. Imar yok, ruhsat yok. Göl sıkışt oraya. Köylü pelli perişan. (K7, Salda Köyü Yerel Halkı, Pazarcı, Erkek). "

"...Geçen yıl 20-30 tan köyün (konteynır) işletmeleri vardı. Kaymakamlık Valilik bunları yıktırdı, jandarma zoruyla kaldırttırdı. Kaymakamlık kendisi yaptırdı. Bu şekilde (ahşaptan) daha hoş olduğunu söylediler...(K8, Salda Köyü Yerel Halkı, Pazarcı, Kadın)."

"Herkesin arazisindeki konteynırları hep kaldırtt devlet. Gölün kenarında saţ̧ yapan çoktu. Mesela benim tarlam var gölün kenarında, yapı yapamıyorum, yaptırmıyorlar. Sit alanı diyorlar, sit alanı neyse. Bina yaptırmıyorlar, çivi bile çaktırmıyorlar. Bir konteynır koyup da sergi açıp da orada alışveriş yaptırmıyorlar, devlet kendisi yapıyor. Adam kendi tapulu arsasına bir şey yapamıyor, yasak. Adamın gölün kenarında tapulu arazisinde (kontaynır işletmesinde) onu bile çalıştırmadılar yav. Ayıp, yemin olsun ayıp. "Ben devletim" diyor Kaymakamlık. Sen kiminle uğraşacaksın. Eski binaları hep yıkt bu devlet. (K5, Salda Köyü Yerel Halkı, Erkek, Emekli)."

Alanın Özel Çevre Koruma bölgesi olmasıyla "turizm merkezi" statüsü kaldırılmış ve göl kumsalına araçların girmemesi için ahşap direkler dikilmiştir. Nitekim göl kenarında özel araçlara karşı koruma altına alınan bu alanlar, önceden belirlenen "mutlak koruma bölgesi" olan I. derece doğal sit alanlarını kapsamaktadır.

"Göl çevresine ahşaptan bilgilendirme panoları koyduk. Araçların sahile geçmemesi için ahşap dubalar koyduk. (K2, il Çevre ve Şehircilik Müdürü, Erkek)."

"iki hafta önce Salda gölünün "turizm merkezi” statüsü fes edildi, ÖÇK'dan (Özel Çevre Koruma) dolayı... (K3, il Turizm Müdürü, Kadın). "

\footnotetext{
"...Bu alanın sulak alan olmasından dolayı, koruma bölgelerini belirlemişiz. Sulak alanların korunması gereği yönetmeliğine göre. Belli bir kısmı mutlak koruma bölgesi ilan etmişiz. Onlar (diğer kurumlar) da bizim bu koyduğumuz mutlak koruma bölgesi statüsü içerisine yapılamayacak şeyleri yapamıyorlar. Mutlak koruma bölgesi içerisine hiçbir şekilde hiçbir yapı, otopark vs. bir şey yapamıyorlar. (K1, Doğa Koruma ve Milli Park Şube Müdürü, erkek). "
}

Göl çevresinde yerel halkın baraka, çadır tarzı işletmeler açmasına izin verilmediği gibi, seyyar arabalar ile satış yapmalarının da yasaklandığı, göl içerisinde tekne, bot ve yelkenli kano faaliyetlerine izin verilmediği ve polis tarafindan alanda sıkı bir denetimin gerçekleştirildiği belirtilmektedir.

“...Gözleme yapılacak gözleme yapmalarına izin vermediler. ... Hiçbir yerde izin vermiyorlar. Ne köfte yapabiliyorsun, ne kokoreç. Aklına gelen hiçbir şeyi yapamıyorsun. Mısır bile sattırmadılar ya. Valilik baskı yapıyor demek ki Emniyete, Emniyet izin vermiyor. Mısır bile sattırmadılar, çok ayıp ya. ...Polis hep var burada, 7/24, Yunuslar da dâhil. Kumsalda çadır kurulmasın, satıcılar olmasın. Onları denetliyorlar...(K4, işletmeci, erkek)."

"Benim yeğenimin 3 tane deniz bisikleti, 3 tane de deniz kanosu vardı. Şurada çalıştıralım dedik, insanlar binsinler. Polis hemen geldi, kaldırtt. Neden dedim, motorlu değil hiçbir şeyli değil. izin aldınız mı? Neden izin alayım ben? Çevre ve Şehircilik'e gittik. "Böyle bir şey mevzuatta yok." ..."Kesinlikle görmeyeceğim" (diyorlar), o kadar. Bitti. Geçen vatandaş yelkenini getirmiş, küçük kano. Yelken açıyor, onu bile polis ıslık çekiyor, korna çalıyor, siren çalıyor buradan, çık dışarı diye. Vatandaşı bu kadar sıkıyorlar. Burası için bi dezavantaj bu. (K4, işletmeci, erkek)."

“Göl nasıl korunacak? Sabah 8'de girilmeli, akşam 8'de orası terk edilmeli. Oradan ayrırılmalı. ...Burası merkezi yönetime bırakılamayacak kadar önemli ve ciddi bir şey. Çünkü yerel yönetim burada ben bu insanlarla birlikte hareket edeceğim. Ankara'dan gelen zihniyet korumaz bunu. Ankara'dan yapılan proje bunu korumaz. Bunu koruyacak olan biziz. ...Gölümüz korunsun. Ama gölü korumayacaklar. Aynı Uzungöl gibi yapacaklar (K12, Yeşilova Belediye Başkanı, erkek). "

\subsection{Kategori 3: Alanın Yönetimine İlişkin Görüşler}

Salda Gölü’nün ÖÇK bölgesi olması ile beraber, yerel yönetimlerin alandaki denetimi artmış ve sıkı bir kontrol ve izleme süreci başlatılmıştır. Bu durum, yerel halkın yerel yönetimlerin bu uygulamalarını eleştirmesini de beraberinde getirmiştir.

"Kaymakamlık daha sıkt bizi burada. Mesela "bunları (deniz şortu, şapka) satmayacaksınız, böyle şeyler getirmeyeceksiniz" (diyor). Ne satacağız tarhana bulgur. Tarhana bulgur da benim buradaki masrafimı çıkarmıyor ki. "Dışardan bir şey getirme, kendi ürününü sat" diyorlar. Sıkıntryı soktu yani bize. (K6, Salda Köyü Yerel Halkı, Pazarcı, Kadın)."

"Salda gölü ile ilgili yerel yönetim şimdiye kadar hiçbir şey söylemedi. Merkezi yönetim yukarıdan bir takım plan proje hazırladı ve I. derecede sit olarak belirtilen yeri güya orada bir şey yapılması yasak derken ÖÇK ilan etti. ...Biz istiyoruz ki burada günübirlik ziyaret olsun, konaklama olmasın. Olmamalı. Çünkü gölün büyüklüğü belli, gölün yapısı belli. Göl, bir okyanus gibi deniz gibi kendi kendisi yenileyemiyor, temizleyemiyor. Burada öyle bir yapı var ki o yapı temizlemeye uygun değil. (i) küçük olması, kapalı olması nedeniyle (ii) oradaki endemik yapısı, kuş türü, oradaki doğal bitki örtüsü nedeniyle yenilemeye uygun değil. Oranın korunması lazım. Koruma nasıl olacak? Günde diyelim oraya 10 bin tane insan girdi. Yapılan tuvaletler (kıyıya) uzak. 10 bin tane insan suya idrarını bırakıyor. Çok kişi tuvalete gitmiyor, suyun içine yapıyor (K12, Yeşilova Belediye Başkanı, erkek)." 
"Yöneticilerin hiçbirisi köylüyü düşünmüyor. Hiçbiri. Tamamen kendi çıkarları veya yandaşlarının menfaatine yönelik çalışmaları var yani. Burası ile belediye değil, Valilik ve Kaymakamlık ilgileniyor... (K7, Salda Köyü Yerel Halkı, Pazarcı, Erkek). "

"Burasına zaten gelecek sene bir şey yaptırmazlar zaten. Millet bahçesi mahkemelik şimdi, o bitti mi buraya başlarlar inşaata. Köylü karşı çıkıyor tabi bu duruma. Köylünün bir şeysi yok ki burada. Millet bahçesine ve hepsine karşı. Buraya gelip gitmelerine bile karşı. Köylü sokulmuyor ki buraya. Köylü turizmin içinde olmak istiyor, kendisi çalıştırmak istiyor, ama veren yok. ...Bizim kafemiz vardı. adamlar geldi, bizim kafemizi köyün içinden kaldırth, konteynır tarzında bir işletmemiz vardı orada. Neymiş, konteynırın yapı işletme ruhsatı olması gerekiyormuş. Biz de ruhsat için başvurumuzu yaptik. Köylüye normalde teşvik olması gerekirken. (K7, Salda Köyü Yerel Halkı, Pazarcı, Erkek). Bir kere idarecilerin turizmden anlaması lazım. Kaymakamlık'a gidiyoruz Valilik i suçluyor, Valilik'e gidiyoruz Kaymakamlığı suçluyor. Milletvekili'ne gidiyoruz, ben konuşurum diyor, o da sallıyor. Idarecinin bi kere turizmden anlaması lazım. (K7, Salda Köyü Yerel Halkı, Pazarcı, Erkek). "

"Bir kere idarecilerin turizmden anlaması lazım. Kaymakamlık'a gidiyoruz Valilik i suçluyor, Valilik'e gidiyoruz Kaymakamlığı suçluyor. Milletvekili'ne gidiyoruz, ben konuşurum diyor, o da salIıyor. Idarecinin bi kere turizmden anlaması lazım. (K7, Salda Köyü Yerel Halkı, Pazarcı, Erkek). "

"Köyün konteynır işletmeleri vardı, geçen yıl kaldırdılar. Şu gördügünüz işletmeler Kaymakamlık'a ait. Üç tane işletme var. Bana dedi ki (yetkili memur): "Çevre ve Şehircilik yeni kanun çıkardı" dedi. "Çevre düzenlemesi yapılacak" dedi. "Yapı işletmeleri olmayanları kaldırıyoruz" dedi. Peki dedim, şurdaki (Kaymakamlığın işlettiği) işletmelerin izinleri var mı? Dedim o gelen adamlara. "Orası devletin" dedi. Devlet suç işliyor ise dedim, niye benim imarlı arsamda bana müsaade etmiyorsun? (K7, Salda Köyü Yerel Halkı, Pazarcı, Erkek). "

"Geçen sene burada köylülerin 15-20 tane işletmeleri vardı, konteynırları vardı. Vali bey dedi: "Burası konteynır çöplüğü olmuş" dedi, herkesi kaldırttırdı. ...Ama köylüyü çıkardılar buradan, kendileri koydular, kendileri yapınca yasak yok, sit alanı yok. Biz yapınca ta bizi imarlı arsadan kaldırdılar. Şimdi sen köyümüzün turizminin kalkınmasını nasıl beklersin. O yasak, bu yasak, şu yasak. Bir şeyler yapmak istiyorsun o da yasak. Bu köy turizmle kalkınır mı hocam? (K7, Salda Köyü Yerel Halkı, Pazarcı, Erkek)."

ÖÇK alanının Salda Köyü’nü de kapsamasından dolayı, köy içerisine yapılan apart-pansiyonların bir kısmının işletme izin belgesi alamadıkları için ruhsatsız çalıştırıldığı görülmektedir:

"Köyde apart var, apart sayısını vermeyelim, ama bana kaç yatak var dersen, ortalama ruhsatlı 100 yatak var derim köyde. Ruhsatsızlarla 250 yatak da olabilir. Yeterli mi değil. ÖçK olduğu için bunlar da şimdi ruhsat alamıyorlar. Hiçbir şey yapamıyorlar, bekliyorlar. (K10, Salda Köyü Muhtarı, erkek). “

Araştırma alanının daha bütüncül bir yönetime kavuşması ve farklı birimlerin gölde ayrı ayrı sorumluluk alanına sahip olmasının önüne geçmek adına, Salda Gölü’nün "milli park" statüsüne alınması Doğa Koruma ve Milli Park Şube Müdürlüğü tarafindan önerilmiş; fakat bu öneri kabul görmemiştir. Alanın farklı statülerinin olması, alanın yönetiminde yetki karmaşasını da ortaya çıkarmaktadır:
"Aslında bir alanın bütüncül olarak yönetilmesi en idealidir. Yani sorumlu tek bir kurum olmalı, tek elden tek bir mevzuat üzerinden sürdürülmesi ideal olanıdır. Ama bizim Türkiye'deki birçok alanda maalesef yetki karmaşası oluyor. Burada da benzer şekilde bir karmaşa söz konusu. Nedir işte burdaki statüler: (i) Alanının tamamının sit statüsünde olması, (ii) sadece belli bir alanın Tabiat Parkı olması ve (iii) yeni getirilen Özel Çevre Koruma Alanı ilan edilmiş olması. ... Tabi birçok kurumun alanı yönetmeye kalkması da bazı zorlukları beraberinde getiriyor. (K1, Doğa Koruma ve Milli Park Şube Müdürü, erkek)."

\subsection{Kategori 4: Ziyaretçi Yoğunluğu ve Planlamaya ilişkin Görüşler}

Salda Gölü'nün sosyal medya, internet ve TV gibi iletişim araçları ile popülerliğini giderek artmış ve tanınırlığının son 2-3 yılda artması, dışardan gelen ziyaretçi sayısının da her geçen gün artmasına neden olmuştur. Gölün kendine özgü rengi olan kumsalı ile "Maldivler" olarak nitelendirilmesi markalaşmasında ve turistik çekiciliğinde önemli bir etken olmuştur.

"Delikanlım, buranın adı sanı yoktu. Aniden patladı, hazırlıksız yakalandı. Iki senedir buranın adı var. Köyün içi almıyor geleni gideni. (K5, Salda Köyü Yerel Halkı, Erkek, Emekli). Son 2-3 yıldır parladı bizim burası... (K11, Kayadibi Mahallesi muhtarı, Erkek). "

2018 yılında Salda Gölü’nü ziyaret eden kişi sayısı 689.730 iken, 2019 yııının ilk 6 ayında 398.439 kişinin alanı ziyaret ettiği görülmektedir. Yukarıda ifade edildiği üzere, Çevre ve Şehircilik Bakanlığı'nın (2019a) yaptı̆̆ı incelemelerde, gelen ziyaretçilerin alanda antropojenik baskıyı artırdığı tespit edilmiştir. Göl alanında turizm kaynaklı görülen ziyaretçi baskısını, "planlama" ve "kontrollü kullanım" ile en aza indirebilmek için, Bakanlık bünyesinde alanda bir takım toplantıların gerçekleştirildiği de belirtilmiştir.

“...Burada önemli olan alanın taşıma kapasitesi. Taşıma kapasitesine göre hareket edilmesi gerekiyor. Eğer taşıma kapasitesinin üzerinde bir şey varsa o zaman bazı geri dönülmeyecek tahribatlar ortaya çıkar diye düşünüyorum. Bu sene buraya 500 bin kişi geldi, seneye bunu 1 milyon yapalım, ondan sonraki sene 2 milyon yapalım gibi hedefler koymamak lazım. Planlamayı çok iyi yapmak lazım burada. Eğer biz taşıma kapasitesinin üzerini zorlarsak o zaman geri dönülemeyecek şeyler ortaya çıkar diye düşünüyorum. (K1, Doğa Koruma ve Milli Park Şube Müdürü, erkek)."

“...Yazın her gün nerdeyse 15 bin insan geldi, Temmuz'da Ağustos ayında. (K7, Salda Köyü Yerel Halkı, Pazarcı, Erkek). "

"Köyümüzde pansiyon çok, köyümüzün içi hep pansiyon. Çok apart var. Yeri müsait olan yapıyor. Yaz boyunca apartlar pansiyonlar hiç boş kalmadı. Daha hatta boş yer bulamadılar. (K9, Salda Köyü, İşkur Çalışanı, Kadın)."

"Bungalov ev hafta sonu hepsi doluydu mesela. Genelde en az iki günlük geliyorlar. Göle giriyorlar. Türkiye'nin her yerinden geliyorlar, inanılmaz. Gelenler bir de gitmek istemiyorlar buradan. Çok beğeniyorlar burayı. (K4, İşletmeci, Erkek). ." 
Yaz aylarında alana özel araçları ile gelen ziyaretçilerin oluşturduğu trafik yoğunluğu Salda Köyü yerel halkı tarafindan çeşitli gerekçelerle eleştirildiği de görülmektedir:

"Köyün içinin trafiği Denizli'den berbatt. Çocuklarımızı sokağa salamıyorduk. Çok kalabalık oluyordu. Gelenlerden memnunuz ama köyün içindeki kalabalıktan memnun değiliz. Çok kalabalık var, çok trafik var. Bizim çocuklarımız yola çıkamıyor, biz çıkamıyoruz. Arabayla Yeşilova'ya bir saatte anca ulaşt eşim. Şu Yeşilova'ya. Trafikten memnun değiliz. Yollar çok hareketlendi. Denizli'den berbat. Insan korkuyor. Çocuğun en doğal hakkı değil mi bisiklet, binemiyor. (K9, Salda Köyü, İşkur Çalışanı, Kadın)."

Çevre ve Şehircilik Bakanlığı tarafindan "Salda Gölü ÖÇK Bölgesi Planı" henüz hazırlanmakta olduğu için, alanın yönetiminde zorluklar görülmektedir. Yapı izni-ruhsat alma ve işletme izni konularında il Çevre ve Şehircilik Müdürlüğü'ne yerel halkın taleplerinin olduğu; ancak alanın ÖçK mevzuatının ve planının henüz hazırlanmamış olmaması nedeniyle bazı idari sıkıntıların yaşandığı görülmektedir:

"...Komisyon izin verdiği sürece ve plana uygun olduğu müddetçe yapı inşasına izin veriliyor. Planda yoksa kimse oraya turizm inşası yapamaz. ...1/25.000'lik plan da çıkmadı henüz, çalışmalar da devam ediyor. Bakanlık yapıyor planı. Plan bittikten sonra asgari şeyler plana göre değerlendirilecek. ...il koordinasyonu çalışıor da şu an biz planı bekliyoruz. Plan olmadan gelen talep ve yazıları biz Ankara'ya gönderiyoruz. Ankara cevabını veriyor, biz de kişiyi bilgilendiriyoruz. (K2, il Çevre ve Şehircilik Müdürü, Erkek)."

"Çevredeki orman arazilerine, yaban hayatına zarar vermeden kurumların planlamalarını yapmaları gerekiyor. Su yapılarının buna göre planlanması gerekiyor. ...Benim temennim yapılacak tesisler doğaya uyumlu olsun, betonlaşma olmasın, hassas yerlerde yapılmasın vs. (K1, Doğa Koruma ve Milli Park Şube Müdürü, Erkek)." "...betonlaşma olmasın. Tahtadan millet bahçesi olacaksa tah-
tadan şeyli olsun...(K6, Salda Köyü Yerel Halkı, Pazarcı, Kadın)."

ÖÇK bölge planı ve millet bahçesi projesi hakkında yerel halkın bilgilendirilmediği ve süreç içerisine kendilerinin katılmadığı belirtilmektedir.

"Denizli yolunun aşağısındaki (göl kenarındaki) tarla sahipleri, "devlet buraları istimlak edecek, elimizden alacak" diyor. Ya herkeste çeşit çeşit bir söylenti var. Arkadaş biz de bir şey bilmiyoruz. Gittiğimiz yerlerde de bize bir şey anlatmıyorlar. ...Tam iyi açıklamacı bir cevap vermiyorlar bize. ... Köylüde bir tedirginlik bir kaygı var. Çevre ve Şehircilik'e bir şey diyemiyoruz ki "yasak, her şey yasak" diyorlar. Ben geçen dedim köylüye, arkadaşlar bakın şimdi tavuk kümesi bile yapsanız bunun cezası var. Ee netcez (diyorlar). Bekleyeceksiniz (diyorum). (K11, Kayadibi Mahallesi muhtarı, Erkek). "

\section{Sonuç}

Salda Gölü, I. ve II. Derecede doğal sit alanı olup, aynı zamanda belli bir kısmı da Tabiat Parkı statüsünde yönetilmektedir. Belirli bir dönem "Turizm Merkezi" statüsü verilen Salda Gölü’nün, ÖÇK bölgesi olması ile birlikte, bu statüsü kaldırılmıştır. Gölün belirli bir kısmının Tabiat Parkı olması, kalan kısmının ÖçK bölgesi olması yetki sahası olarak farklı Bakanlıkların yönetimsel alanı içerisinde kalmasına neden olmaktadır. Bu durum da koordinasyon ve yönetimde parçalı bir yapıyı oluşturmakta, havzanın bütüncül olarak korunması ve yönetimini zorlaştırmaktadır. Bu nedenle Salda Gölü sulak alanının "bütüncül bir yönetim planı" içerisinde yönetilmesi sağlanmalıdır.

Bu araştirmada; kurumsal raporlar ve paydaşlardan elde edilen bulgular ile korunan alan statüsündeki Salda Gölü’nün ziyaretçi yoğunluğu, koruma kullanım durumu ve sürdürülebilirliği anlaşılmaya çalışılmıştır. Gölün doğal kaynak değerlerinin yeterince korunduğu, ancak ÖÇK Planı henüz hazırlanmadığı için, yerel halkın yerel yönetimlerin denetimlerinden ve idari uygulamalarından memnun kalmadığı görülmektedir.

Salda Köyü plaj alanında yerel halkın konteynırlar içerisinde çay, gözleme gibi ürünler satmasının yerel yönetimlerce yasaklanması, Yeşilova Kaymakamlığı'nın göl kenarına yaptırmış olduğu işletmelerde bu ürünlerin satılması yerel halk tarafindan eleştirilmekte; yerel halkın turizmin dışına itildiği belirtilmektedir. Ayrıca kıl çadır ve bungalov ev yapımına ve işletimine izin (ruhsat) verilmediği; buna rağmen Yeşilova Belediyesi'nin göl kenarında bungalov evlerde konaklama hizmeti verdiği yerel halk tarafindan memnuniyetsizlikle karşılanmaktadır. Salda Köyü içerisinde pansiyon ve apart otel şeklinde hizmet veren kişilerin bir kısmının ÖÇK bölgesi nedeniyle henüz ruhsat alamadığı ve ruhsatsız olarak işletmecilik yaptığı görülmektedir.

Yerel yönetimlerin denetleme, izleme, kontrol ve ceza kesme işlemleri alanın korunmasını sağlamakta, ancak sürdürülebilir kullanımını zorlaştırmaktadır. Diğer bir deyişle, havzanın ekolojik hassasiyetinin yanında ekonomik ve sosyal yönü düşünülmeli, göl çevresinde yaşayan yerel halkın göl çevresindeki tarım, hayvancılık ve turizm faaliyetlerine kontrollü ve denetimli bir şekilde izin verilmesi ve bunun da bir planlama dahilinde gerçekleştirilmesi gerekmektedir. Ayrıca Salda Gölü kenarına yapılacak "Millet Bahçesi" içerisindeki rekreasyonel işletme ihalelerine yerel halkın katılımı sağlanmalı ve yerel halkın turizmin içinde olmasına önem verilmesi gerekmektedir. Böylece göl alanından yerel halkın ekonomik olarak faydalanması sağlanarak sürdürülebilir kırsal kalkınmanın gerçekleştirilmesi mümkün olacaktır.

Araştırma alanına yılda yaklaşık 700 bin kişinin giriş yapması, bu insanların bir kısmının göle girmesi ve beyaz kumsalda ayakkabıları ile yürümesi, piknik ve kamp-karavan faaliyetleri ile çevreye kat atklar bırakması gibi durumlar gözlemlenmiştir. Pamukkale travertenlerinde olduğu gibi, Salda Gölü beyaz kumsallarında ayakkabısız gezinme-yürüme gibi uygulamalar ile bu antropojenik baskının azaltılması düşünülmektedir. Ancak yerel yönetimlerce Salda Gölü'ne gelecek ziyaretçi sayısının 1 milyona çıkarılma düşüncesi, daha fazla kirlilik ve çöp, daha fazla trafik sıkışıkığı ve park sorunu demektir. Tüm bunlar, göl ekosisteminin korunmasını güçleştirecektir. 
Bu nedenle göl havzasının orman ve kumul ekosisteminin korunması öncelikli olarak düşünülmelidir.

Salda Gölü ÖÇK bölgesi olmasının yanı sıra, aynı zamanda içerisinde "Millet Bahçesi" olarak nitelendirilen bir rekreasyonel kullanım alanının da oluşturulması gündemdedir. Millet Bahçesi içerisine kafe, restoran, mescit ve çocuk oyun alanı gibi sosyal donatıların oluşturulacağı ve işletmelerin ihale ile kişilerin işletimine verileceği belirtilmektedir. Millet Bahçesi'ne yapılacak işletmelerin dışardan ihaleye girenlere verileceği ve göl kıyılarının giderek imara ve yapılaşmaya açılacağı yönünde yerel halk üzerinde kaygıların olduğu yapılan görüşmelerde görülmektedir.

Salda gölü çevresine Millet Bahçesi'nin yapılması, alana dışardan günübirlik gelen yoğun ziyaretçi dışında, çevredeki il ve ilçe merkezlerinden de alana günübirlikçi gelmesine ve alanın yoğun bir şekilde kullanılmasına neden olacaktır. Bu nedenle hassas bir alan olan Salda Gölü'nün ziyaretçi yönetim planının yapılması, fiziksel taşıma kapasitesinin çok iyi hesaplanması gerekmektedir. Aksi durumda, korunan göl havzası ziyaretçi baskısı altında daha fazla kalarak hassas orman ve kumul ekosistemi daha fazla zarar görecektir.

Korunan bir alan olan Salda Gölü'nün aynı zamanda turizmin de içinde olması nedeniyle, yoğun bir yapılaşma-betonlaşma ve asfalt yollar oluşturma gibi uygulamalardan uzak duracak bir planlama ile yönetilmesi sağlanmalıdır. Başka bir deyişle, göl ekosistemi için turizm bir tehdit oluşturmamalıdır. Aksi durumda, Doğu Karadeniz Bölgesi'nde yer alan Uzungöl ve Ayder Yaylası'ndaki yanlış yapılaşma ve amaç dışı kullanım gibi durumlar görülebilecektir.

Çevre ve Şehircilik Bakanlığı'nda hazırlanmakta olan Salda Gölü ÖÇK Bölge Planı́nın hazırlanmasında çevre bilimci, jeolog, coğrafyacı, turizmci ve sosyolog bilim insanlarından destek alınmalı; yerel halkın görüşleri ve talepleri alınarak planlama içerisine dâhil edilmeleri sağlanmalıdır. Ayrıca hazırlanmakta olan planın "sürdürülebilir göl turizmi" yaklaşımında hazırlanması ve alanı yönetiminde (korunması ve işletiminde) sürdürülebilirlik ilkelerinin uygulanması sağlanmalıdır.

Salda Gölü ziyaretçi giriş ücretlerinin ve Yeşilova KaymakamIığı'nın göl kenarındaki işletmelerden (bungalov evler, kafe, büfe vb.) elde etiği gelirlerin bir kısmı alanın korunması için ayrılmalıdır. Ayrılacak bu bütçe ile gölün su seviyesinin korunması için yapılacak bilimsel teknik çalışmalar desteklenmeli, gölün giriş-çıkışlarının ve ziyaretçi alanlarının kontrol edilebilmesi için yeterli sayıda görevli (bekçi) bu bütçeden sağlanmalıdır. Ayrıca gölün plaj girişine Ziyaretçi Tanıtım Merkezi oluşturulmalı, alanın ekolojik hassasiyetini ve önemini belirten bilgilendirmeler bu merkezlerde yapılmalıdır.

Salda Gölü'nün 40 km doğusunda bulunan Yarışlı Gölü’nün kurumuş olması, iklim değişikliklerinin göllerin geleceğini tehdit ettiğinin en yakın ve açık göstergesidir. Bu nedenle, Salda Gölü'nün göl seviye değişimlerinin dikkatle izlenmesi, havza su yönetim planının oluşturulması ve mevcut göl su seviyesinin korunması sağlanmalıdır. Başka bir deyişle, küresel ısınma kaynaklı iklim değişikliklerinin Salda Gölü'nün beslenmesini en az etkilemesi yönünde planlamaların yapılması ve (tarım ve turizme yönelik) uygulamaların bu doğrultuda gerçekleştirilmesi gerekmektedir. Böylece gölün sürdürülebilir gelişimi sağlanmalı ve bütüncül alan yönetimi doğrultusunda gölün ekolojik hassasiyeti gözetilmelidir.

\section{Kaynakça}

Akgül, E., Korhan, Ç, Kavurmacı, H.F., Karaman, B.,Erşen, D., Güngör Y. (2017). Güncel Hidroman yazit Stromatolitleri ve SaldaGölü (1014 Nisan2017), 70. Türkiye Jeoloji Kurultayı.

Akpınar, E., Akbulut, G. (2007). Hafik Gölü ve Yakın Çevresinin Turizm Olanakları, Erzincan Eğitim Fakültesi Dergisi, 9(1): 1-24.

Aydın, M. (2015). Lake Tourism Potential: Ulubat and Gölyazı,International Journal of Business and Management Studies, 4(2):179-189.

Balcı, N., Demirel, C., Kurt, M.A. (2018). Salda Gölünün Jeomikrobiyolojisi ve Güncel Stromatolit Oluşumunda Mikrobiyal Etkiler,Hacettepe Üniversitesi Yerbilimleri Dergisi, 39(1): 19-40.

Birinci, S., Zaman, M., Bulut, I. (2016). Limni Gölü TabiatParkının Rekreasyonel Potansiyeli, Uluslararası Sosyal Araştırmalar Dergisi,9(46) :285-294.

Braithwaite, C.J.R., Zedef, V. (1996). Hydromagnesite Stromatolites and Sediments in an Alkaline Lake, Salda Gölü, Turkey. Journal of Sedimentary Research, 66, 9911002.

Bulut, I.., Zaman, M., Kopar, I., Artvinli, E. (2008a). GözeDağı (Yalnızçam Dağları) Kuzeybatısındaki Arşiyan Yaylasında Göller ve YüzenAdalar, Atatürk Üniversitesi Edebiyat Fakültesi Sosyal Bilimler Dergisi, 8: 133-153.

Bulut, I.., Kopar, I.., Zaman, M. (2008b). Karadeniz Bölgesindeki Yüzen Adalara Yeni Bir Örnek: Zökün Gölü Yüzen Adaları (Tortum),Atartürk Üniversitesi Edebiyat Fakültesi Sosyal Bilimler Dergisi,8(41): 215230.

Bulut, ì., Ceylan, S. (2011). Ekolojik Sorunları ve Fonksiyolarıyla Niğde Yöresi Yapay Gölleri, Atatürk Üniversitesi Sosyal Bilimler Enstitüsü Dergisi,15(2): 263-288.

Bulut, í. (2012). Türkiye'nin Yüzen Adaları. Erzurum: Atatürk Üniversitesi Yayınları Edebiyat Fakültesi Yayın No. 138.

Bulut, i., Kopar, İ., Zaman, M. (2013). Mezra Gölü (Kılıçkaya-YusufeliArtvin) ve Yüzen Adaları, Atatürk Üniversitesi Edebiyat Fakültesi Sosyal Bilimler Dergisi,50: 11-24.

Bulut, I., Çağlar-Karapınar, B., Özoğul, B. (2016). Karakuyu Gölü(Afyonkarahisar-Dinar) ve Yüzen Adaları, TÜCAUM Uluslararası Coğrafya Sempozyumu (13-14 Ekim 2016) Bildiriler Kitabı,Ankara, s.366-378.

Burdur il Kültür ve Turizm Müdürlüğü, (2014). Salda Turizm Merkezi, Gül Ofset, Burdur.

Ceylan, M.A. (2006). Yayla Gölü (Buldan) ve Rekreasyon Potansiyeli , Doğu Coğrafya Dergisi, 16, 323-351.

Daubariene, J. (2009). The Influence of Lakes on the TourismDevelopment in Utena County, Sociālo Zinātṇu Žurnāls Nr. 1(2): 77-86.

Dokulil, M.T. (2014). Environmental Impacts of Tourism on Lakes, Inside (Eds: A.A. Ansari, S.S. Gill) Eutrophication: Causes, Consequences and Control. Springer Science+Business Media,81-88.

Güney, E. (2004). Türkiye Hidrografyası. İstanbul: Çantay Kitabevi.

Goeldner, C. R., Ritchie, J. R. and. McIntosh, R. W (2000). Tourism.Principles, Practises, Philosophies. Eight Edition.John Wiley\& Sons,Inc.New York.

Kaiser, J., Ön, B., Arz, H., Akçer-Ön, S. (2016). Sedimentary Lipid Biomarkers in the Magnesium Rich and Highly Alkaline LakeSalda(Southwestern Anatolia). Journal of Limnology, 75(3),581-596.

Kapan, K. (2016). Development and Sustainability of the Tourism inLake Salda and its Environs" Inside (Ed. C.Avcıkurt, M.S.Dinu, N.Hac ıoğlu, R.Efe, A.Soykan, N.Tetik) Global Issues and Trends in Tourism.St Kliment Ohridski University Press,Sofia. 
Kazancı, N., Girgin, S., Dügel, M., Oğuzkurt, D., Mutlu, B., Dere, Ş., Barlas, M., Özçelik.M. (1999). Köyceğiz, Beyşehir, Eğirdir, Akşehir, Eber, Çorak, Kovada, Yarışlı, Bafa, Salda, Karataş, Çavuşçu Gölleri, Küçük ve Büyük Men deres Deltası, Güllük Sazlığı, Karamuk Bataklığı'nın Limnolojisi, Çevre Kalitesi ve Biyoçe- şitliliği. Türkiye İç Suları Araştormaları Dizisi: IV. Ankara: İmaj Yayınevi.

Kazancı, N., Girgin, S., Dügel, M. (2004). On the Limnology of Salda lake, A Large and Deep soda lake in Southwes-tern Turkey: Future MaMa-nagement Proposals, Aquatic Conservation.Aquatic Conservation: Marine and Freshwater Ecosystems,14, 151-162.

Kurleto, M. (2013). Sustainable Management of Lakes Taking into Con sideration the Tourism and Nature Conservation in Australia and New Zeland, Polish Journal of Natural Sciences, 28(1):91-106.

Lehtolainen, M. (2003). Public Infrastructure Investments and Their Role in Tourism Development in the Finnish Lake Region.www.matttailu.org/jarvimatkailu/pdf/mi-ka iltcpaper.pdf

Lerner, M. and Haber, S. (2000). Performance Factors of Small Tourism Ventures: The Interface of Tourism, Entrepreneurship and the Environment. Journal of Business Venturing, Vol 16, pp. 77-100.

Orman ve Su İşleri Bakanlığı (2013). "Salda Gölü Sulak Alan Alt Havzası Biyoçeşitlilik Araştırma Proje Raporu”, Ortadoğu OrmancılıkProje Etüt ve Müşavirlik, Ankara.

Orman ve Su İşleri Bakanlığı (2017a). Salda Gölü Tabiat Parkı Gelişme Planı: Planlama Raporu, Ankara: Doğa Koruma ve Milli Parklar Genel Müdürlüğü.

Orman ve Su İşleri Bakanlığı (2017b). Salda Gölü Tabiat Parkı Gelişme Planı: Analitik Etüt ve Sentez Raporu. Ankara: Doğa Koruma ve Milli Parklar Genel Müdürlüğü.

Russel, M.J., Ingham, J.K., Zedef, V., Maktav, D., Sunar, F., Hall, A.J., Fallick, A.E. (1999). Search for signs of ancient life on Mars: Expectaions from Hydromagnesite Microbialites, Salda Lake, Turkey, Journal of the Geological Society, 156: 869-888

Ryhanen, H. (2003). The Tourist Profile and Potential of European Lake Destinations. Retrieved from: www.joensuu.fi/skk

Sunlu, U. (2003). Environmental Impacts of Tourism, Inside (Eds. Camarda D., Grassini, L.) Local Resources and Global Trades: Environments and Agriculture in the Mediterranean Region. Environmen talMonitoring and Assessment, Bari: CIHEAM, p.263-270.

Yiğit, A. (1994). Hazar Gölü'nün Turizm Potansiyeli ve Bugünkü Kullanım Durumu, Fırat Üniversitesi Sosyal Bilimler Dergisi, 6(1-2).

Zeybek, H.i. (2005). Kaz Gölü Ekosistemi (Tokat) Türkiye 5. Kuvaterner Sempozyumu (02-03 Haziran 2005), iтÜ Avrasya Yer Bilimleri Enstitüsü, s. 235.240 .

İnternet Kaynakları

Abercrombie, T. (2019). "Potential Effect from Tourism and Recreation on Aquatic Ecosystems", Regional Aquatics Monitoring Program (RAMP),http://www.rampalberta.org/resources/tourism/wildlifeaspx (Erişim Tarihi: 16.10.2019).

Aydın, Z., Şensoy-Boztepe, A., Karadağ, K. (2019). "Salda Gölü Yapılaşma Olmadan korunacak"https://www.aa.com.tr/tr/yasam httyasam/salda-golu- yapilasma-olmadan-korunacak-/1546938 (Erişim Tarihi: 21.12.2019).

Burdur II Kültür ve Turizm Müdürlüğü, (2019). “Turizm Aktiviteleri”http://burdur.ktb.gov.tr/TR-154591/turizm-aktiviteleri.html (Erişim Tarihi: 27.07.2019).
Burdur İl Kültür ve Turizm Müdürlüğü (2019b). “istatiksel Veriler”,https://burdur.ktb.gov.tr/TR-155327/istatistikler-ve-veriler.html (Erişim Tarihi: 08.08.2019).

Çevre ve Şehircilik Bakanlığı (2019a). "Salda Gölü Doğal Sit Alanı”,Tabiat Varlıklarını Koruma Genel Müdürlüğü,https://tvk.csb.gov.tr/salda-golu-dogal-sit-alani-haber-231661 (Erişim Tarihi:11.08.2019) Çevre ve Şehircilik Bakanlığı (2019b). "Salda Gölü Özel Çevre Koruma Bölgesinde Çalışma Ziyareti, https://tvk.csb.gov.tr/salda-golu-ockbolgesine-calisma-ziyareti-haber-239278 (Erişim Tarihi: 18.09.2019). ILEC- International Lake Environment Committee Foundation (2019). “Overview, Vision: Save Lakes", https://www.ilec.or.jp/en/about/ (Erişim Tarihi: 19.09.2019).

Kültür ve Turizm Bakanlığı (2013). Antalya Kültür ve Tabiat Varlıklarını Koruma Bölge Kurul Müdürlüğü'nün 118 Toplant Gündemi" http:// https://docplayer.biz.tr/amp/16428409-T-c-kultur-ve-turizm-bakanligi-antalya-kultur-ve-tabiat-varliklarini-koruma-bolge-kurulu-mudurlugu-118-toplanti-gundemi.html (Erişim Tarihi: 13.08.2019).

Web 1: "Salda Gölü Projesi” (Erişim Tarihi:16.10.2019).https//www.facebook.com/brdryesilova/photos/a.124338815590214/12433922 $5590173 /$ ?type $=3 \&$ theater 